\title{
Inclusion effect of soybean meal, fermented soybean meal, and Saccharina japonica in extruded pellet for juvenile abalone (Haliotis discus, Reeve 1846)
}

Ahyeong Yun ${ }^{1}$, June Kim', Hae Seung Jeong², Ki Wook Lee², Hee Sung Kim², Pil Youn Kim³ and Sung Hwoan $\mathrm{Cho}^{{ }^{* *}}$ (D)

\begin{abstract}
Inclusion effect of soybean meal (SBM) and fermented SBM (FSM) in extruded pellet for juvenile abalone (Haliotis discus) was compared in abalone farm. Dietary inclusion effect of the combined macroalgae (MA) (Undaria pinnatifida and Hizikia fusiforme) and a single Saccharina japonica on abalone was also compared. Three thousand six hundred juvenile abalone were purchased from a private hatchery and acclimated to the experimental conditions for 2 weeks. Six 5-ton flow-through raceway tanks were used, and abalone were randomly distributed into tanks ( $n=600$ per tank). Three experimental diets were prepared in duplicate. Fish meal, FSM, corn gluten meal, and shrimp meal and wheat flour and dextrin were used as the protein and carbohydrate sources, respectively, in the FSM diet. MA was also included in the FSM diet. FSM and MA in the FSM diet were substituted with SBM at the expense of wheat flour and S. japonica, referred to as the SBM and SJ diets. The experimental diets were pelletized by an extruded pelleter. Water stability of nutrients in the experimental diets was monitored at 12,24 , and $48 \mathrm{~h}$ after seawater immersion. The experimental diets were fed to abalone once a day to satiation with a little leftover for 120 days. The retained crude protein and lipid and ash content of the extruded pellets were changed over all period of time. Weight gain and specific growth rate (SGR) of abalone fed the SBM diet were greater than those of abalone fed the FSM and SJ diets. Weight gain and SGR of abalone fed the SJ diet were also greater than those of abalone fed the FSM diet. The longest shell length, widest shell width, highest shell height, and greatest soft body weight were obtained in abalone fed the SBM diet, followed by the SJ and FSM diets. Proximates of the soft body of abalone were not different among the experimental diets. In conclusion, SBM was a superior protein source to FSM in extruded pellet for growth performance of abalone. Dietary inclusion of a single S. japonica was superior to the combined inclusion of U. pinnatifida and H. fusiforme in the production of abalone.
\end{abstract}

Keywords: Abalone Haliotis discus, Soybean meal (SBM), Fermented soybean meal (FSM), Macroalgae (MA), Saccharina japonica, Extruded pellet

\footnotetext{
* Correspondence: chosunh@kmou.ac.kr

${ }^{1}$ Division of Marine Bioscience, Korea Maritime and Ocean University, Busan

49112, South Korea

Full list of author information is available at the end of the article
}

(c) The Author(s). 2018 Open Access This article is distributed under the terms of the Creative Commons Attribution 4.0 International License (http://creativecommons.org/licenses/by/4.0/), which permits unrestricted use, distribution, and reproduction in any medium, provided you give appropriate credit to the original author(s) and the source, provide a link to the Creative Commons license, and indicate if changes were made. The Creative Commons Public Domain Dedication waiver (http://creativecommons.org/publicdomain/zero/1.0/) applies to the data made available in this article, unless otherwise stated. 


\section{Background}

Annual world aquaculture production of abalone (Haliotis spp.) increased from 2542 to 139,594 metric tons in 2000 and 2015 and from 20 to 12,346 metric tons in 2000 and 2016 in Korea (FishStatJ 2017). It expects to increase in future due to high demand for human consumption and the expansion of abalone farms. Therefore, many feeding trials, such as determination of dietary nutrient requirement (Uki et al. 1986; Mai et al. 1995a, b; Britz 1996; Gómez-Montes et al. 2003; Thongrod et al. 2003), development of alterative protein source for casein and fish meal (Uki et al. 1986; Lee et al. 1998; Guzman and Viana 1998; Bautista-Teruel et al. 2003; Cho et al. 2008; Cho 2010; Jung et al. 2016; Myung et al. 2016; Lee et al. 2017), development of alternative terrestrial and marine by-product sources for macroalgae (MA) (Reyes and Fermin 2003; Kim et al. 2016; Lee et al. 2017; Jang et al. 2018) and development of formulated feed (Viana et al. 1993; Britz et al. 1994; Lee 1998; Garcia-Esquivel and Felbeck 2009) for stable abalone production have been performed.

Soybean meal (SBM) has been commonly used as an alternative protein source for fish meal in animal feeds including aquafeed for long time due to not only its low cost and stable supply, but also its high protein content (40-50\%) with well-balanced amino acid profiles compared to other plant protein sources, which are likely to be deficient in lysine, tryptophan, threonine, isoleucine, or valine (Emmert and Baker 1997; Boonyaratpalin et al. 1998; Storebakken et al. 2000; Kim et al. 2012). SBM has been successfully substituted for either casein, which achieved the best performance, or fish meal in abalone (H. discus hannai) feed without retardation in growth (Uki et al. 1985; Lee et al. 1998). Cho (2010) also reported that growth performance of abalone $(H$. discus hannai) fed the diet containing the combined SBM and corn gluten or silkworm pupae meal was superior to that fed a fish meal-basal diet.

Dietary inclusion rate of SBM is known to be rather restricted in monogastric animal including fish due to the anti-nutritional factors, such as trypsin inhibitor, tannins, oligosaccharide, and phytic acid (NRC 1993; Francis et al. 2001; Guimaraes et al. 2008). Fermentation is one of the methods to lower these anti-nutritional factors and improve major nutrient content in SBM (Shimeno et al. 1993a, b; Hong et al. 2004; Yamamoto et al. 2010; Gao et al. 2013; Kook et al. 2014). Shimeno et al. (1993b) showed that growth and feed efficiency of yellowtail (Seriola quinqueradiata) fed the pellet containing fermented SBM (FSM) were superior to those of fish fed the pellet containing SBM, resulted from the fact that FSM improved digestibility of dietary protein and carbohydrate and lowered dietary trypsin inhibitor and oligosaccharides content. Wang et al. (2016) also reported that SBM could substitute with up to $30 \%$ of fish meal and $45 \%$ for FSM, respectively, in turbot (Scophthalmus maximus) diet.

Nevertheless, dietary inclusion of SBM and cottonseed meal fermented with Aspergillus oryzae did not improve growth performance, but lowered feed efficiency of Nile tilapia (Oreochromis niloticus) although fermentation lowered dietary and liver gossypol content (Lim and Lee 2011). Dietary substitution effect of FSM for fish meal was rather limited in black sea bream (Acanthopagrus schlegelii) (Zhou et al. 2011). Oral administration of commercially available FSM (PepSoyGen) did not improve growth performance and feed efficiency of white seabass (Atractoscion nobilis) and yellowtail jack (Seriola lalandi) (Trushenski et al. 2014). Kim et al. (2009) also reported that dietary inclusion of FSM would rather depress growth performance and feed efficiency of parrot fish (Oplegnathus fasciatus) although fermentation improved availability of phosphorous and non-specific immune response of fish.

Therefore, dietary inclusion effect of SBM and FSM on performance of fish is still controversial. In addition, Lee et al. (2017) reported that substitution effect of FSM with fish meal was very limited when 50\% fish meal at $14 \%$ was replaced with FSM in commercial abalone (H. discus hannai) feed. Recently, Kim et al. (2017) reported that SBM was a superior protein source to FSM in abalone feed when the experimental diets with 25\% SBM and FSM were fed to juvenile abalone ( $H$. discus). Still, inclusion effect of SBM and FSM in commercial feed on abalone is unknown.

About $15-30 \%$ of macroalgae (MA), such as Undaria pinnatifida or Saccharina japonica depending on their price and seasonal availability is commonly included in commercial abalone feed in Korea (Hernández et al. 2009; O'Mahoney et al. 2014; Jang et al. 2018). Administration of the combined two of three MA (Gracilaria tenuistipitata, S. japonica, and Gelidium japonica) produced an improved growth performance of abalone ( $H$. asinina) over a single MA (Yu et al. 2014). However, Qi et al. (2010) showed that the combined MA (S. japonica and Gracilaria tenuistipitata or Sargassum pallidum) produced poor weight gain for 2-year old abalone (H. discus hannai) over a single MA (S. japonica or G. tenuistipitata).

In this study, therefore, inclusion effect of SBM and FSM in extruded pellet on juvenile abalone $(H$. discus, Reeve1846) was compared in abalone farm. In addition, dietary inclusion effect of the combined MA (U. pinnatifida and Hizikia fusiforme) and a single S. japonica on abalone was compared.

\section{Methods}

Preparation of abalone and rearing conditions

Three thousand six hundred juvenile abalone were purchased from a private hatchery and transferred to 
Deagun abalone farm (Jeju Special Self-Governing Province, Korea). Before an initiation of the feeding trial, abalone were acclimated to the experimental conditions for 2 weeks and fed with dry $U$. pinnatifida once a day at a ratio of $2-3 \%$ total biomass.

Six 5-ton concrete flow-through raceway tanks ( $4.3 \mathrm{~m} \times 0.9 \mathrm{~m} \times 1.1 \mathrm{~m}$; water volume 1.5 ton) with a flow rate of $47.7 \mathrm{~L} / \mathrm{min}$ were used for this experiment $(n=2$ per diet). Juvenile abalone $[5.7 \pm 0.24 \mathrm{~g}($ mean $\pm \mathrm{SD})]$ were randomly distributed into tanks ( $n=600$ per tank). Sand-filtered seawater, at a temperature ranging from 12.5 to $19.8{ }^{\circ} \mathrm{C}$ (mean $\pm \mathrm{SD} 16.0 \pm 1.92{ }^{\circ} \mathrm{C}$ ), was supplied during the feeding trial. Aeration was supplied into each raceway tank, and photoperiod followed natural conditions. The experimental diets were fed to abalone once a day $(17: 00 \mathrm{~h})$ to satiation with a little leftover (about 2-3\% total biomass). Dead abalone were removed daily, and the bottoms of the tanks were siphon-cleaned twice a week. The feeding trial lasted for 120 days. At the end of the feeding trial, 200 abalone were randomly chosen from each raceway tank and then collectively weighed to determine weight gain.

\section{Preparation of the experimental diets}

Three experimental diets were prepared (Table 1). Thirteen percent fish meal, 23\% FSM, 4.4\% corn gluten meal, and 3\% shrimp meal and $26 \%$ wheat flour and $4 \%$ dextrin were used as the protein and carbohydrate sources, respectively, in the FSM diet. Twenty-three percent macroalgae (MA), a mixture of Undaria pinnatifida and Hizikia fusiforme at a ratio of 1:1, was included in the FSM diet. Twenty-three percent FSM and MA in the FSM diet were substituted with $30 \%$ SBM at the expense of wheat flour and same amount of S. japonica, referred to as the SBM and SJ diets, respectively, to produce isonitronic diets. All diets were formulated to meet the dietary nutrient requirements of abalone (Uki et al. 1986; Mai et al. 1995a, b). The three experimental diets were pelletized by an extruded pelleter (Jyoda, Japan) at Ewha Oil and Fat Industry Co. Ltd. (Busan, Korea).

\section{Growth measurements}

One hundred abalone at the start from an extra tank and 50 abalone from each tank at the termination of the feeding trial were sampled and frozen for analysis. Prior to examination, all samples were slightly thawed, followed by separation of the shell and soft body tissue. Shell length, width, and height were measured to a precision of $1.0 \mathrm{~mm}$ with a digital caliper (Mitutoyo Corporation, Kawasaki, Japan), and the ratio of soft body weight to whole body weight (the soft body weight + shell) was calculated to determine a condition index for abalone. Specific growth rate (SGR; \%/day) was calculated using the formula of Britz (1996): SGR $=[(\ln (W f)$
Table 1 Ingredients of the experimental diets (\%, dry matter basis)

\begin{tabular}{|c|c|c|c|}
\hline & \multicolumn{3}{|c|}{ Experimental diets } \\
\hline & $\begin{array}{l}\text { Fermented } \\
\text { soybean meal } \\
\text { (FSM) }\end{array}$ & $\begin{array}{l}\text { Soybean } \\
\text { meal } \\
\text { (SBM) }\end{array}$ & $\begin{array}{l}\text { Saccharina } \\
\text { japonica (SJ) }\end{array}$ \\
\hline \multicolumn{4}{|l|}{ Ingredient } \\
\hline White fish meal & 13 & 13 & 13 \\
\hline $\begin{array}{l}\text { Fermented soybean meal } \\
\text { (CP } 56.1 \%, C L 1.0 \%)\end{array}$ & 23 & & 23 \\
\hline $\begin{array}{l}\text { Soybean meal } \\
\text { (CP 46.0\%, CL 2.2\%) }\end{array}$ & & 30 & \\
\hline Corn gluten meal & 4.4 & 4.4 & 4.4 \\
\hline Shrimp meal & 3 & 3 & 3 \\
\hline $\mathrm{MA}^{1}(\mathrm{CP} 15.1 \%, \mathrm{CL} 2.5 \%)$ & 23 & 23 & \\
\hline $\begin{array}{l}\text { Saccharina japonica } \\
\text { (CP 17.2\%, CL 2.1\%) }\end{array}$ & & & 23 \\
\hline Wheat flour & 26 & 19 & 26 \\
\hline Dextrin & 4 & 4 & 4 \\
\hline Spirulina & 0.6 & 0.6 & 0.6 \\
\hline Yeast & 0.2 & 0.2 & 0.2 \\
\hline Sea aroma & 0.1 & 0.1 & 0.1 \\
\hline Choline chloride (50\%) & 0.5 & 0.5 & 0.5 \\
\hline Vitamin premix ${ }^{2}$ & 0.2 & 0.2 & 0.2 \\
\hline Mineral premix ${ }^{3}$ & 2 & 2 & 2 \\
\hline \multicolumn{4}{|l|}{ Nutrients (\%) } \\
\hline Dry matter & 89.2 & 92.5 & 91.5 \\
\hline Crude protein & 37.0 & 37.1 & 37.5 \\
\hline Crude lipid & 2.1 & 2.7 & 1.8 \\
\hline Carbohydrate $^{4}$ & 44.5 & 43.9 & 50 \\
\hline Ash & 16.4 & 16.3 & 10.7 \\
\hline
\end{tabular}

${ }^{1} \mathrm{MA}$ is a mixture of Undaria pinnatifida and Hizikia fusiforme at a ratio of 1:1 ${ }^{2}$ Vitamin premix contained the following amount which were diluted in cellulose ( $\mathrm{g} / \mathrm{kg} \mathrm{mix}$ ): riboflavin, 23.8; pyridoxine, 4.7; niacin, 95.2; Ca-pantothenate, 33.3; inositol, 476.9; folic acid, 1.5; p-amino benzoic acid, 47.6; filler, 31.7 ${ }^{3}$ Mineral premix contained the following ingredients ( $\mathrm{g} / \mathrm{kg} \mathrm{mix}$ ): $\mathrm{MgSO}_{4}, 140.8$; $\mathrm{NaH}_{2} \mathrm{PO}_{4}, 92.4 ; \mathrm{KH}_{2} \mathrm{PO}_{4}, 246 ; \mathrm{Ca}\left(\mathrm{H}_{2} \mathrm{PO}_{4}\right)_{2}, 139.5 ; \mathrm{ZnSO}_{4}, 22.5 ;$ Ca-lactate, 310; $\mathrm{AlCl}_{3}, 0.15 ; \mathrm{KI}, 0.15 ; \mathrm{MnSO}_{4}, 2 ; \mathrm{CoCl}_{2}$, 1 ; filler, 45.5

${ }^{4}$ Carbohydrate was calculated by difference $(100-\%$ crude protein $-\%$ crude lipid - \% ash)

$-\operatorname{In}(\mathrm{Wi})) /$ days of feeding] $\times 100$, where $\operatorname{In}(\mathrm{Wf})=$ natural $\log$ of the final mean weight of abalone and $\operatorname{In}(\mathrm{Wi})=$ natural $\log$ of the initial mean weight of abalone.

Proximate analysis of abalone flesh and water stability of nutrients in the diets

The pooled separated soft body tissue from the sampled abalone from each tank was then homogenized and used for proximate analysis. Crude protein content was estimated from total nitrogen using the Kjeldahl method (Auto Kjeldahl System, Buchi B-324/435/412, Switzerland). Crude lipid was determined using an ether-extraction method, moisture was determined by oven drying at $105^{\circ} \mathrm{C}$ for $24 \mathrm{~h}$, and ash was determined using a muffle furnace at 
$550{ }^{\circ} \mathrm{C}$ for $4 \mathrm{~h}$. All methods were according to AOAC (1990) practices.

The three extruded diets were placed in separate 70-L plastic rectangular containers $(120 \mathrm{~cm} \times 36 \mathrm{~cm})$ without abalone in duplicate. These containers were then placed within a 5-ton concrete flow-through raceway tank at a flow rate of $45.6 \mathrm{~L} / \mathrm{min}$ and subsampled at 12,24 , and $48 \mathrm{~h}$ to evaluate leaching of nutrients in the diets to determine their water stability. Nutrient levels in the diets were assessed using the same procedure described above for the abalone flesh. Water stability of nutrients in the diets was expressed as the percentage of final dry content to initial dry content for each nutrient based on Mai et al. (1995a).

\section{Statistical analysis}

One-way ANOVA and Duncan's multiple range test (Duncan 1955) were used to determine the significance of the differences among the means of treatments by using SAS version 9.3 program (SAS Institute, Cary, NC, USA). Water stability of the experimental diets was tested by ANOVA with repeated measurement designs (Cody and Smith 1991). Percentage data was arcsine-transformed prior to statistical analysis.

\section{Results}

The retained crude protein content of the extruded pellets was significantly $(P<0.0001)$ changed over all period of time; however, no significant difference was found among the extruded pellets within the same time (Fig. 1).

Crude lipid content of the extruded pellets was significantly $(P<0.0001)$ changed over all period of time; however, no significant difference was found among the extruded pellets, except at 48 immersion in seawater (Fig. 2). Crude lipid content of the SBM diet was significantly $(P<0.05)$ higher than that of the SJ diet, but not significantly $(P>0.05)$ different from that of the FSM diet at $48 \mathrm{~h}$ after seawater immersion.

Ash content of the extruded pellets was significantly $(P<0.0001)$ changed over all period of time, and their significant $(P<0.003)$ interactions (pellets $\times$ time) were also observed (Fig. 3). The retained ash content of the SBM and FSM diets was significantly $(P<0.05)$ higher than that of the SJ diet at 24 and $48 \mathrm{~h}$ after seawater immersion.

Survival of abalone ranging from 90.4 to $93.5 \%$ was not significantly $(P>0.05)$ different among the experimental diets (Table 2). Weight gain and SGR of abalone fed the SBM diet were significantly $(P<0.05)$ greater than those of abalone fed the FSM and SJ diets. Weight gain and SGR of abalone fed the SJ diet were also significantly $(P<0.05)$ greater than those of abalone fed the FSM diet.

The longest shell length, widest shell width, highest shell height, and greatest soft body weight were obtained in abalone fed the SBM diet, followed by the SJ and FSM diets (Table 3 ) although no statistically significant difference was observed between the SBM and SJ diets. However, no significant difference in the ratio of soft body weight to total weight of abalone was observed.

Proximates of soft body of abalone were not significantly $(P>0.05)$ affected by the experimental diets (Table 4$)$.

\section{Discussion}

Greater weight gain and SGR of abalone fed the SBM diet compared to the FSM diet in this study indicated that SBM was better utilized than FSM as protein source

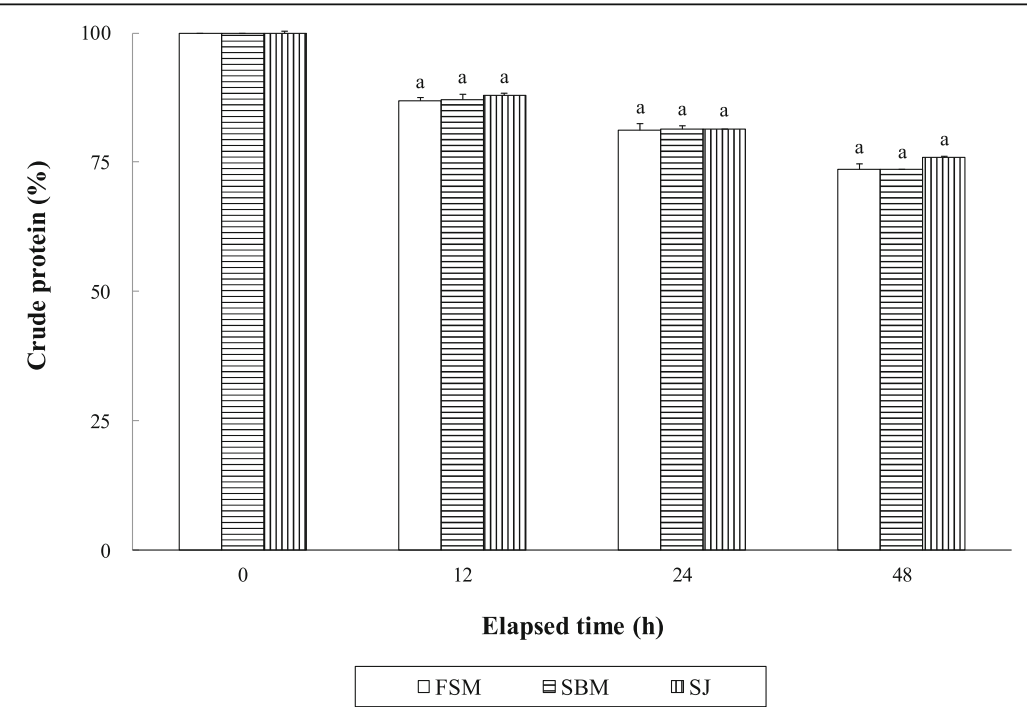

Fig. 1 Changes of crude protein content in the extruded pellets at 12,24, and $48 \mathrm{~h}$ after seawater immersion (means of duplicate \pm SE). [ANOVA with repeated design: time $(P<0.0001)$ ]. Different letters in each time point indicate difference between diets within each time point 


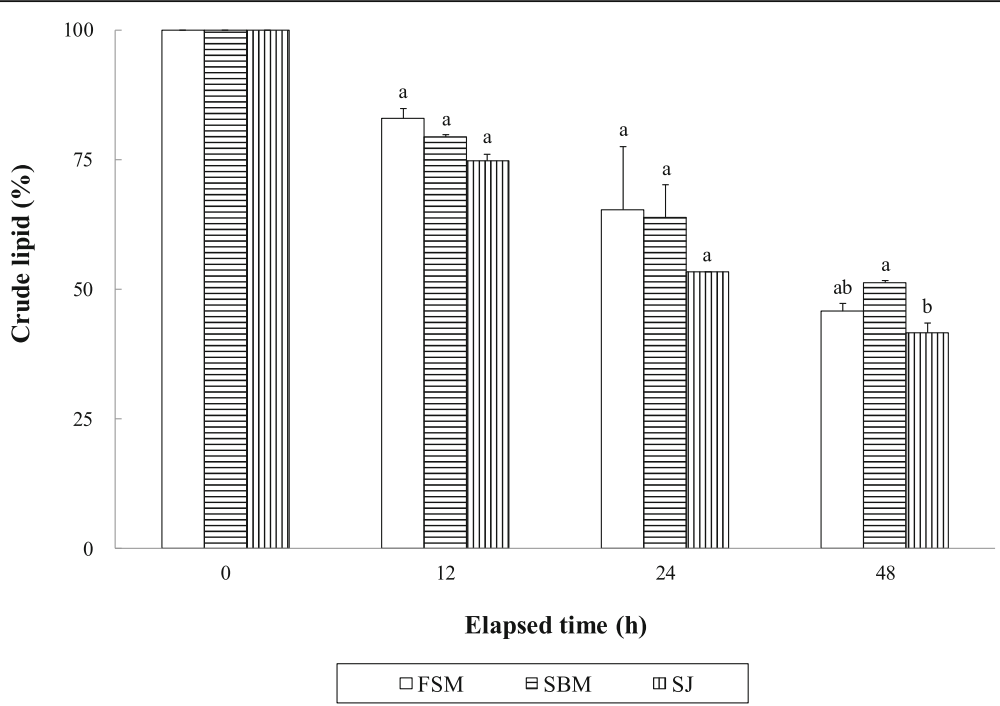

Fig. 2 Changes of crude lipid content in the extruded pellets at 12, 24, and $48 \mathrm{~h}$ after seawater immersion (means of duplicate \pm SE). [ANOVA with repeated design: time $(P<0.0001)$ ]. Different letters in each time point indicate difference between diets within each time point

in extruded abalone feed. This result confirmed that SBM was a superior protein source to FSM when juvenile abalone ( $H$. discus) were fed with one of the experimental diets containing $25 \%$ SBM and FSM for 16 weeks (Kim et al. 2017). SGR in abalone (an initial weight of $3.0 \mathrm{~g}$ ) fed the diet containing $25 \%$ FSM was estimated to be 0.49 and $0.54 \%$ /day for $25 \% \mathrm{SBM}$, respectively, and $10.2 \%[(0.54-0.49) /(0.49)=10.2 \%]$ of SGR of fish fed the latter improved in Kim et al.'s (2017) study; on the other hand, $69.7 \%[(0.56-0.33) /(0.33)=69.7 \%]$ of SGR in abalone fed the SBM diet (0.56 vs $0.33 \% /$ day $)$ improved in this study. Favorable inclusion effect of SBM in extruded pellet on growth of abalone becomes clear.

Since abalone are eating MA, such as Undaria or Saccharina containing 40-50\% carbohydrate content (Fleming et al. 1996) in wild, utilizing them as energy sources better than lipid (Britz et al. 1994; Monje and Viana 1998; Thongrod et al. 2003), antinutrient factors do not deteriorate growth performance of abalone. In general, herbivorous and omnivorous fish species seem to accept plant-origin feed ingredients and utilize well (Robinson and Li 1994; El-Saidy and Gaber 2002; Hardy

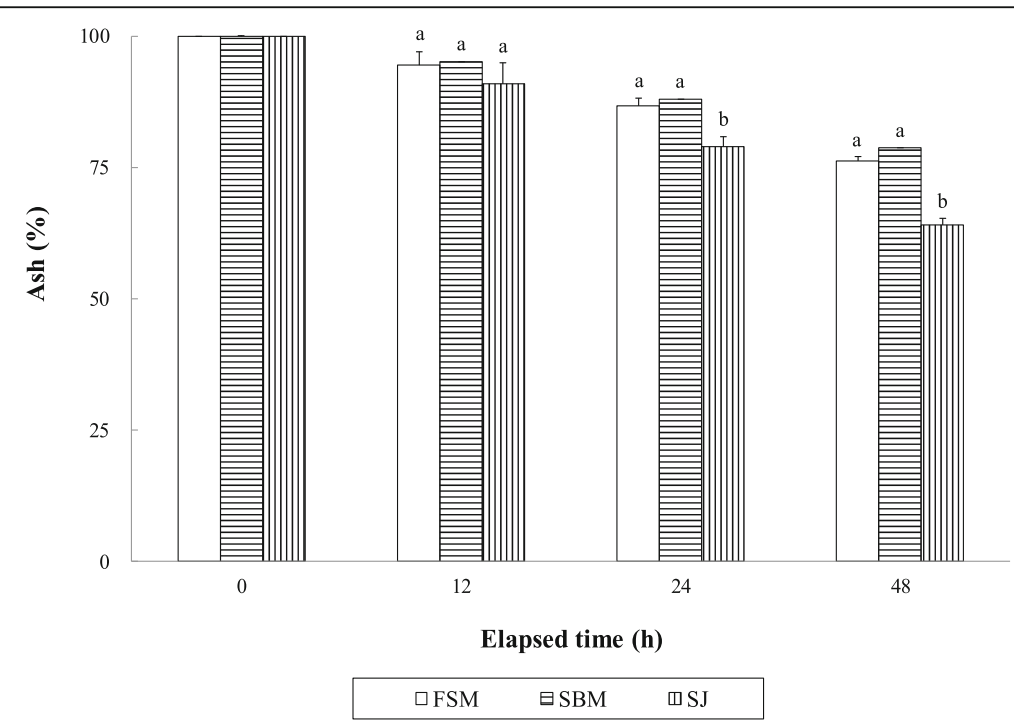

Fig. 3 Changes of ash content in the extruded pellets at 12, 24, and $48 \mathrm{~h}$ after seawater immersion (means of duplicate \pm SE). [ANOVA with repeated design: time $(P<0.0001)$ and their interaction (pellets $\times$ time) $(P<0.003)$ ]. Different letters in each time point indicate difference between diets within each time point 
Table 2 Survival (\%), weight gain (g/abalone), and specific growth rate (SGR; \%/day) of juvenile abalone fed the extruded pellets for 120 days

\begin{tabular}{|c|c|c|c|c|c|}
\hline Experimental diets & Initial weight (g/abalone) & Final weight (g/abalone) & Survival (\%) & Weight gain (g/abalone) & $\mathrm{SGR}^{1}$ (\%/day) \\
\hline$\overline{F S M}$ & $5.7 \pm 0.08^{a}$ & $8.5 \pm 0.04^{b}$ & $92.3 \pm 0.32^{\mathrm{a}}$ & $2.8 \pm 0.04^{c}$ & $0.33 \pm 0.018^{c}$ \\
\hline SBM & $5.5 \pm 0.02^{a}$ & $10.7 \pm 0.16^{a}$ & $93.5 \pm 1.04^{a}$ & $5.2 \pm 0.14^{a}$ & $0.56 \pm 0.010^{a}$ \\
\hline SJ & $6.0 \pm 0.32^{\mathrm{a}}$ & $9.9 \pm 0.28^{a}$ & $90.4 \pm 1.90^{\mathrm{a}}$ & $4.0 \pm 0.04^{b}$ & $0.43 \pm 0.022^{b}$ \\
\hline
\end{tabular}

Values (means of duplicate $\pm \mathrm{SE}$ ) in the same column sharing a common superscript are not significantly different $(P>0.05)$

${ }^{1}$ Specific growth rate $(S G R ; \% /$ day $)=[(\operatorname{Ln}(W f)-\operatorname{Ln}(W i)) /$ days of feeding $] \times 100$, where $\operatorname{Ln}(W f)=$ natural log of the final mean weight of abalone and $\operatorname{Ln}($ Wi $)=$ natural log of the initial mean weight of abalone

2010; Trushenski et al. 2014). Similarly, dietary inclusion of FSM and fermented cottonseed meal did not affect growth performance of Nile tilapia (Lim and Lee 2011), and oral administration of FSM would even rather depress growth performance and feed efficiency of parrot fish (Kim et al. 2009). Trushenski et al. (2014) also reported that dietary inclusion of commercially available FSM did not improve growth performance and feed efficiency of white seabass and yellowtail jack when fish meal was replaced with the combined traditional SBM and FSM in feed. Matsunari et al. (2010) showed that FSM did not improve growth performance and feed efficiency of rainbow trout (Oncorhynchus mykiss) when fish meal was completely replaced with either the combined SBM or FSM and corn gluten meal in diet.

Unlike this study, however, the conflicting results that oral administration of FSM improved digestibility of dietary protein and carbohydrate, but lowered dietary trypsin inhibitor and oligosaccharide content (Shimeno et al. 1993a; Francis et al. 2001; Hong et al. 2004; Yamamoto et al. 2010; Gao et al. 2013; Kook et al. 2014) were reported. Dietary inclusion of fermented plant protein source improved growth performance of fish (Shimeno et al. 1993b; Zhou et al. 2011; Wang et al. 2016). Especially, Yamamoto et al. (2010) reported that lower digestibility values of carbohydrate and lipid observed in rainbow trout fed the diet containing FSM with Bacillus spp. with an initial water addition of $30 \%$ for $10 \mathrm{~h}$ were highly improved and it resulted to comparable growth and feed efficiency of fish even to fish fed the fish meal-basal diet. They concluded that FSM is a promising ingredient as the main protein source in a non-fish meal diet for rainbow trout. Therefore, practical application of fermentation technique to plant protein source in diet should be carefully considered depending on targeting animals, strain used for fermentation, and fermentation conditions, for example (Shimeno et al. 1993a, b; Matsunari et al. 2010; Yamamoto et al. 2010; Gao et al. 2013; Trushenski et al. 2014; Kim et al. 2017).

Greater weight gain and SGR of abalone fed the SJ diet compared to the FSM diet indicated that a single $S$. japonica achieved better growth performance of abalone over the combined MA (a mixture of $U$. pinnatifida and $H$. fusiforme at a ratio of $1: 1$ ) in extruded pellet. Although direct comparison in the inclusion effect of a single (S. japonica) and the combined MA (a mixture of $U$. pinnatifida and $H$. fusiforme) on growth of abalone could not be made due to difference in MA species used in the SJ and FSM diets in this study, a similar result that juvenile abalone ( $H$. discus) averaging 4.3 g grew better on $S$. japonica over $U$. pinnatifida at mean temperature of $19.5{ }^{\circ} \mathrm{C}$ (Lee et al. 2016) would be reported. Qi et al. (2010) also reported that the highest weight gain was obtained in 2-year old abalone $(H$. discus hannai) fed S. japonica, followed by Gracilaria lemaneiformis, the combined $S$. japonica and G. lemaneiformis, Sargassum pallidum, and combined $S$. japonica and S. pallidum when five different combination of MA were fed to abalone for 4 months. However, further study to determine direct comparison effect of MA ( $S$. japonica, $U$. pinnatifida, $H$. fusiforme or their combination) on performance of abalone is needed in future.

Although abalone are slow eaters, water stability of the supplied feed can be one of the most important factors in determining growth performance of abalone and discharged water pollution sources from farms. The retained crude protein and lipid and ash content in the extruded pellets were changed with time in this study, but no distinctive difference was found in either crude protein or crude lipid except at $48 \mathrm{~h}$ after in seawater immersion.

Table 3 Shell length, shell width, shell height, soft body weight, and the ratio of soft body weight to total weight of abalone fed the extruded pellets for 120 days

\begin{tabular}{llllll}
\hline Experimental diets & Shell length $(\mathrm{mm})$ & Shell width $(\mathrm{mm})$ & Shell height $(\mathrm{mm})$ & Soft body weight $(\mathrm{g})$ & Soft body weight/total weight \\
\hline FSM & $40.5 \pm 0.27^{\mathrm{b}}$ & $27.9 \pm 0.50^{\mathrm{b}}$ & $7.9 \pm 0.19^{\mathrm{b}}$ & $3.8 \pm 0.17^{\mathrm{b}}$ & $0.61 \pm 0.010^{\mathrm{a}}$ \\
SBM & $45.4 \pm 0.45^{\mathrm{a}}$ & $30.9 \pm 0.06^{\mathrm{a}}$ & $9.3 \pm 0.03^{\mathrm{a}}$ & $5.7 \pm 0.00^{\mathrm{a}}$ & $0.62 \pm 0.000^{\mathrm{a}}$ \\
SJ & $43.6 \pm 0.44^{\mathrm{a}}$ & $30.3 \pm 0.25^{\mathrm{a}}$ & $8.9 \pm 0.03^{\mathrm{a}}$ & $5.1 \pm 0.05^{\mathrm{a}}$ & $0.59 \pm 0.002^{\mathrm{a}}$
\end{tabular}

Values (means of duplicate $\pm \mathrm{SE}$ ) in the same column sharing a common superscript are not significantly different $(P>0.05)$ 
Table 4 Chemical composition (\%) of soft body of juvenile abalone fed the extruded pellets for 120 days

\begin{tabular}{lllll}
\hline Experimental diets & Moisture & Crude protein & Crude lipid & Ash \\
\hline FSM & $78.6 \pm 1.18^{\mathrm{a}}$ & $16.6 \pm 0.45^{\mathrm{a}}$ & $2.1 \pm 0.04^{\mathrm{a}}$ & $2.6 \pm 0.04^{\mathrm{a}}$ \\
SBM & $76.8 \pm 0.12^{\mathrm{a}}$ & $17.6 \pm 0.49^{\mathrm{a}}$ & $2.2 \pm 0.04^{\mathrm{a}}$ & $2.7 \pm 0.12^{\mathrm{a}}$ \\
SJ & $74.5 \pm 0.24^{\mathrm{a}}$ & $16.5 \pm 0.04^{\mathrm{a}}$ & $2.0 \pm 0.00^{\mathrm{a}}$ & \\
\hline
\end{tabular}

Values (means of duplicate \pm SE) in the same column sharing a common superscript are not significantly different $(P>0.05)$

Water stability of nutrients in extruded pellets obtained in this study seems to be rather high than those reported in other studies (Bautista-Teruel et al. 2003; Gómez-Montes et al. 2003; Lee et al. 2016; Lee et al. 2018a, b), but comparable to that reported by Mai et al. (1995a).

None of proximates of soft body of abalone was affected by the experimental diets in this study. However, unlike this study, the chemical composition of soft body of abalone was commonly affected by dietary nutrient content (Mai et al. 1995a, b; Thongrod et al. 2003; Cho et al. 2008; Garcia-Esquivel et al. 2009; Cho 2010; Kim et al. 2016; Myung et al. 2016; Kim et al. 2017; Lee et al. 2018a, b).

\section{Conclusions}

In conclusion, the retained crude protein and lipid and ash contents in extruded pellet were changed with time. Soybean meal was a superior protein source to fermented soybean meal in extruded pellet for weight gain and specific growth rate of juvenile abalone. Biological measurements (shell length, width, and height and soft body weight) of abalone reinforced the result found to the growth rate. Dietary inclusion of a single macroalgae, $S$. japonica, produced better growth performance of abalone rather than the combined inclusion of macroalgae, $U$. pinnatifida and $H$. fusiforme.

\section{Abbreviations}

FSM: Fermented soybean meal; MA: Macroalgae; SBM: Soybean meal; SGR: Specific growth rate; SJ: Saccharina japonica

\section{Acknowledgements}

This research was supported by Basic Science Research Program through the National Research Foundation of Korea (NRF) funded by the Ministry of Science, ICT \& Future Planning.

\section{Funding}

The design of the study, collection, analysis, and interpretation of the data and writing of the manuscript were supported by Basic Science Research Program through the National Research Foundation of Korea (NRF) funded by the Ministry of Science, ICT \& Future Planning (2017R1A2B4009773).

\section{Availability of data and materials}

All datasets generated during and/or analyzed during the current study are available from the corresponding author on reasonable request.

\section{Authors' contributions}

SHC designed the study and prepared the draft. HSJ, KWL, and PYK ran the feeding trial. JK, AY, and HSK analyzed the chemical composition of the diets and carcass of abalone. All authors read and approved the final manuscript.

\section{Ethics approval}

All experimental protocols followed the guidelines of the Institutional Animal Care and Use by Committee of the Korea Maritime and Ocean University.
Consent for publication

Not applicable

\section{Competing interests}

The authors declare that they have no competing interests.

\section{Publisher's Note}

Springer Nature remains neutral with regard to jurisdictional claims in published maps and institutional affiliations.

\section{Author details}

'Division of Marine Bioscience, Korea Maritime and Ocean University, Busan 49112, South Korea. ${ }^{2}$ Department of Convergence Study on the Ocean Science and Technology, Korea Maritime and Ocean University, Busan 49112, South Korea. ${ }^{3}$ Ocean and Fisheries Research Institute, Jeju Special Self-Governing Province, Jeju 63358, Korea.

Received: 22 March 2018 Accepted: 11 July 2018

Published online: 28 September 2018

\section{References}

AOAC (Association of Official Analytical Chemists). Official methods of analysis. 15th ed. Arlington: Association of Official Analytical Chemists; 1990.

Bautista-Teruel MN, Fermin AC, Koshio SS. Diet development and evaluation for juvenile abalone, Haliotis asinina: animal and plant protein sources. Aquaculture. 2003;219:645-53.

Boonyaratpalin M, Suraneiranat $P$, Tunpibal T. Replacement of fish meal with various type of soybean products in diets for the Asian seabass, Lates calcarifer. Aquaculture. 1998;161:67-78.

Britz PJ. Effect of dietary protein level on growth performance of South African abalone (Haliotis midae) fed fishmeal-based semi-purified diets. Aquaculture. 1996;140:55-61.

Britz PJ, Hecht T, Knauer J, Dixon MG. The development of an artificial feed for abalone farming. S Afr J Sci. 1994;90:7-8.

Cho SH. Effect of fishmeal substitution with various animal and/or plant protein sources in the diet of the abalone Haliotis discus hannai Ino. Aquac Res. 2010;41:e587-93.

Cho SH, Park J, Kim C, Yoo J. Effect of casein substitution with fishmeal, soybean meal and crustacean meal in the diet of the abalone Haliotis discus hannai Ino. Aquac Nutr. 2008;14:61-6.

Cody RP, Smith JK. Applied statistics and the SAS programming language. 3rd ed. Englewood Cliffs: Prentice-Hall; 1991. p. 163-206.

Duncan DB. Multiple range and multiple F tests. Biometrics. 1955;11:1-42.

El-Saidy DMS, Gaber MMA. Complete replacement of fish meal by soybean meal with dietary I-lysine supplementation for Nile tilapia, Oreochromis niloticus, fingerlings. J World Aquacult Soc. 2002;33:297-306.

Emmert JL, Baker DH. A chick bioassay approach for determining the bioavailable choline concentration in normal and overheated soybean meal, canola meal and peanut meal. J Nutr. 1997;127:745-52.

FishStatJ. Food and Agriculture Organization of the United Nations. Rome; 2017.

Fleming AE, Barneveld RJV, Hone PW. The development of artificial diets for abalone: a review and future directions. Aquaculture. 1996;140:5-33.

Francis G, Makkar HPS, Becker K. Antinutritional factors present in plant-derived alternate fish feed ingredients and their effects in fish. Aquaculture. 2001;199: 197-227.

Gao Y, Wang C, Zhu Q, Qian G. Optimization of solid-state fermentation with Lactobacillus brevis and Aspergillus oryzae for trypsin inhibitor degradation in soybean meal. J Integr Med. 2013;12:869-76. 
Garcia-Esquivel Z, Felbeck H. Comparative performance of juvenile red abalone, Haliotis rufescens, reared in laboratory with fresh kelp and balanced diets. Aquac Nutr. 2009;15:209-17.

Gómez-Montes L, Garcia-Esquivel Z, D'Abramo LR, Shimada A, Va'squez-Pela'ez C, Viana MT. Effect of dietary protein:energy ratio on intake, growth and metabolism of juvenile green abalone Haliotis fulgens. Aquaculture. 2003;220: 769-80.

Guimarães LG, Pezzato LE, Barros MM. Amino acid availability and protein digestibility of several protein sources for Nile tilapia, Oreochromis niloticus. Aquac Nutr. 2008;12:396-404.

Guzmán JM, Viana MT. Growth of abalone Haliotis fulgens fed diets with and without fish meal, compared to a commercial diet. Aquaculture. 1998;165:321-31.

Hardy RW. Utilization of plant proteins in fish diets: effects of global demand and supplies of fishmeal. Aquac Res. 2010;41:770-6.

Hernández J, Uriarte I, Viana MT, Westermeier R, Farías A. Growth performance of weaning red abalone (Haliotis rufescens) fed with Macrocystis pyrifera plantlets and Porphyra columbina compared with a formulated diet. Aquac Res. 2009; 40:1694-172.

Hong KJ, Lee CH, Kim SW. Aspergillus oryzae 3.042GB-107 fermentation improves nutritional quality of food soybean and feed soybean meals. J Med Food. 2004;7:430-5.

Jang B, Kim PY, Kim HS, Lee KW, Kim HJ, Choi DG, Cho SH, Min B, Kim K, Han H. Substitution effect of sea tangle (ST) (Laminaria japonica) with tunic of sea squirt (SS) (Halocynthia roretzi) in diet on growth and carcass composition of juvenile abalone (Haliotis discus, Reeve 1846). Aquac Nutr. 2018;24:586-93.

Jung W, Kim HS, Lee KW, Kim YE, Choi DK, Jang B, Cho SH, Choi CY, Kim B, Joo Y. Growth and body composition effects of tuna byproduct meal substituted for fish meal in the diet of juvenile abalone, Haliotis discus. J World Aquacult Soc. 2016;47:74-81.

Kim SS, Galaz GB, Pham MA, Jang JW, Oh DH, Yeo IK, Lee KJ. Effects of dietary supplementation of a Meju, fermented soybean meal, and Aspergillus oryzae for juvenile parrot fish (Oplegnathus fasciatus). Asian-Aust J Anim Sci. 2009;22:849-56.

Kim HS, Jeong HS, Choi DG, Jang B, Kim HJ, Lee KW, Cho SH. Effects of dietary inclusion of soybean meal and fermented soybean meal on growth and body composition of juvenile abalone Haliotis discus (Reeve 1846). Kor J Fish Aquat Sci. 2017:50:812-7.

Kim YE, Myung SH, Kim HS, Jung W, Cho SH, Jwa MS, Kim PY, Park M, Kim B. Effect of dietary substitution of sea tangle (ST), Laminaria japonica with rice bran (RB) on growth and body composition of juvenile abalone (Haliotis discus). Aquac Res. 2016;47:1202-8.

Kim EJ, Utterback PL, Parsons CM. Comparison of amino acid digestibility coefficients for soybean meal canola meal, fish meal, and meat and bone meal among 3 different bioassays. Poult Sci. 2012;91:1350-5.

Kook M, Cho S, Hong Y, Park H. Bacillus subtilis fermentation for enhancement of feed nutritive value of soybean meal. J Appl Biol Chem. 2014;57:183-8.

Lee S. Evaluation of economical feed formulation for abalone (Haliotis discus hannai). J Aquaculture. 1998:11:159-66.

Lee KW, Kim HS, Choi DG, Jang BI, Kim HJ, Yun A, Cho SH, Min B, Kim K, Han H. 2017. Effects of the substitution of fish meal (FM) and macroalgae (MA) with soybean meal and rice bran in a commercial juvenile abalone (Haliotis discus hannai) diet on growth performance. Turk J Fish Aquat Sci. 2017;17:519-26.

Lee KW, Kim HS, Jeong HS, Kim J, Yun A, Cho SH. Effect of dietary carbohydrateto-lipid ratio on growth and carcass composition of juvenile abalone, Haliotis discus, reeve 1846. J World Aquacult Soc. 2018b. https://doi.org/10.1111/jwas. 12485.

Lee KW, Kim PY, Kim HS, Jeong HS, Kim J, Yun A, Cho SH. Substitution effect of white radish (Raphanus sativus L.)' by-product and tunic of sea squirt (Halocynthia rorentzi, von Drasche) for Undaria pinnatifida in feed of abalone (Haliotis discus, Reeve 1846). Fish Aquatic Sci. 2018a;21:1-8

Lee KW, Kim HS, Yun A, Choi DG, Jang BI, Kim HJ, Cho SH, Joo Y, Kim B, Min B. Effect of the formulated diets on performance and resistance of juvenile abalone [Haliotis discus (Reeve, 1846)] subjected to various stress conditions. J Shellfish Res. 2016;35:481-91.

Lee S, Yun SJ, Hur B. Evaluation of dietary protein sources for abalone (Haliotis discus hannai). J Aquaculture. 1998;11:19-29.

Lim S, Lee K. A microbial fermentation of soybean and cottonseed meal increases antioxidant activity and gossypol detoxification in diets for Nile tilapia, Oreochromis niloticus. J World Aquacult Soc. 2011;42:494-503.

Mai K, Mercer JP, Donlon J. Comparative studies on the nutrition of species of abalone, Haliotis tuberculata L. and Haliotis discus hannai Ino. III. Responses of abalone to various levels of dietary lipid. Aquaculture. 1995a;134:65-80.
Mai K, Mercer JP, Donlon J. Comparative studies on the nutrition of two species of abalone, Haliotis tuberculata L. and Haliotis discus hannai Ino. IV. Optimum dietary protein level for growth. Aquaculture. 1995b;136:165-80.

Matsunari H, Iwashita Y, Suzuki N, Saito T, Akimoto A, Okamatsu K, Sugita T, Yamamoto T. Influence of fermented soybean meal-based diet on the biliary bile status and intestinal and liver morphology of rainbow trout Oncorhynchus mykiss. Aquaculture Sci. 2010;58:243-52.

Monje $\mathrm{H}$, Viana MT. The effect of cellulose on the growth and cellulolytic activity of abalone Haliotis fulgens when uses as an ingredient in formulated artificial diet. J Shellfish Res. 1998;17:667-71.

Myung SH, Jung W, Kim HS, Kim YE, Cho SH, Jwa MS, Kim PY, Kim MK, Park M, Kim B. Effects of dietary substitution of fishmeal with the combined dry microalgae, Nannochloropsis oceanica (NO) biomass residue and casein on growth and body composition of juvenile abalone (Haliotis discus). Aquac Res. 2016:47:341-8.

NRC (National Research Council). Nutritional requirements of fish. Washington DC: National Academic Press; 1993.

O'Mahoney M, Rice O, Mouzakitis G, Burnell G. Towards sustainable feeds for abalone culture: evaluating the use of mixed species seaweed meal in formulated feeds for the Japanese abalone, Haliotis discus hannai. Aquaculture. 2014;430:9-16.

Qi Z, Liu H, Li B, Mao Y, Jiang Z, Zhang J, Fang J. Suitability of two seaweeds, Gracilaria lemaneiformis and Sargassum pallidum, as feed for the abalone Haliotis discus hannai Ino. Aquaculture. 2010;300:189-93.

Reyes OS, Fermin AC. Terrestrial leaf meals or freshwater aquatic fern as potential feed ingredients for farmed abalone Haliotis asinina (Linnaeus 1758). Aquac Res. 2003;34:593-9.

Robinson EH, Li MH. Use of plant proteins in catfish feeds: replacement of soybean meal with cottonseed meal and replacement of fish meal with soybean meal and cottonseed meal. J World Aquacult Soc. 1994;25:271-6.

Shimeno S, Masumoto T, Mima T, Ando Y. Improvement of nutritive value of soybean meal diet through fermentation. Aquacult Sci. 1993a;41:113-7.

Shimeno S, Mima T, Yamomoto O, Ando Y. Effects of fermented defatted soybean meal in diet on the growth, feed conversion, and body composition of juvenile yellowtail (Seriola quinqueradiata). Nip Sui Gak. 1993b;59:1883-8

Storebakken T, Refstie S, Ruyter B. In: Drackley JK, editor. Soy in animal nutrition: soy products as fat and protein sources in fish feeds for intensive aquaculture. Savoy: Federated Animal Science Society; 2000. p. 127-70.

Thongrod S, Tamtin M, Chairat C, Boonyaratpalin M. Lipid to carbohydrate ratio in donkey's ear abalone (Haliotis asinina, Linne) diets. Aquaculture. 2003;225: 165-74.

Trushenski JT, Rombenso AN, Page M. Traditional and fermented soybean meals as ingredients in feeds for white seabass and yellowtail jack. North Am J Aquac. 2014;76:312-22.

Uki N, Kemuyama A, Watanabe T. Nutritional evaluation of several protein sources in diets for abalone Haliotis discus hannai. Bull Jpn Soc Sci Fish. 1985; 51:1835-9.

Uki N, Kemuyama A, Watanabe T. Optimum protein level in diets for abalone. Bull Jpn Soc Sci Fish. 1986;52:1005-12.

Viana MT, López LM, Salas A. Diet development for juvenile abalone Haliotis fulgens evaluation of two artificial diets and macroalgae. Aquaculture. 1993: 117:149-56.

Wang Q, He G, Mai K, Xu W, Zhou H. Fishmeal replacement by mixed plant proteins and maggot meal on growth performance, target of rapamycin signaling and metabolism in juvenile turbot (Scophthalmus maximus L.). Aquac Nutr. 2016;22:752-8.

Yamamoto T, Iwashita Y, Matsunari H, Furuita H, Akimoto A, Okamatsu K, Suzuk $\mathrm{N}$. Influence of fermentation conditions for soybean meal in non-fish meal diet on the growth performance and physiological conditions of rainbow trout Oncorhynchus mykiss. Aquaculture. 2010:309:173-80.

Yu SN, Duan ZL, Huang B, Wang YL, Wang XB, Li Y, Zhang SF, Zhang YD, Wang T, Qiu $Y$. Effects of different diet combination on the growth of juvenile abalone (Haliotis asinine Linnaeus). Anim Feed Sci Technol. 2014:194:106-12.

Zhou F, Song W, Shao Q, Peng X, Xiao J, Hua Y, Owari BN. Partial replacement of fish meal by fermented soybean meal in diets for black sea bream, Acanthopagrus schlegelii, juveniles. J World Aquacult Soc. 2011;42:184-97. 